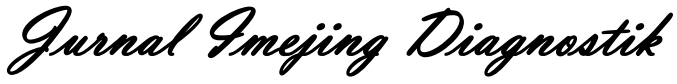

e-ISSN 2621-7457, p-ISSN 2356-301X

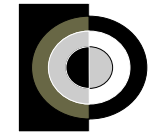

http://ejournal.poltekkessmg.ac.id/ojs/index.php/jimed/index

\title{
Perbandingan Pegukuran Volume Tumor Brain MRI Menggunakan Teknik Manual Dan Metode Active Contour
}

\author{
Maizza Nadia Putri ${ }^{1}$; Irwan Katili²; Ahmad Hariri ${ }^{3}$ Tri Asih Budiati ${ }^{4}$, Gatot Murti Wibowo ${ }^{5}$ \\ 1) Stikes Guna Bangsa Yogyakarta, Indonesia \\ ${ }^{2,5)}$ Poltekkes Kemenkes Semarang, Indonesia \\ 3,4) Pertamina Central Hospital Jakarta, Indonesia \\ Corresponding author: Maizza Nadia Putri \\ e-mail: nadiaputri1596@gmail.com
}

Received: January 29 , 2021; Revised: January 30 $0^{\text {st }}, 2021$; Accepted: February $31^{\text {st }}, 2021$

\begin{abstract}
Background: A brain tumor is a mass of brain cells that grow abnormally. In radiological terms, a brain tumor is called a space occupying lesion (SOL) which generally means a lump. Radiologists or radiology specialists in identifying brain tumors will analyze the results of Magnetic Resonance Imaging (MRI) Brain images with post-processing techniques using a menu in a 3D editor called the region growing technique.

Methods:This type of research is a quasi-experimental research design using Posttest Only Without Control Group Design. The research plan will be carried out at Hermina Hospital Bekasi using 32 samples of brain tumor MRI images, the sample size is obtained by the sample size formula for two paired populations according to Sastroasmoro (2011). Bivariate data analysis, if the data is normally distributed ( $\mathrm{p}$ value $>0.05$ ), then the Paired T-test statistical test is performed and if the data is not normally distributed ( $\mathrm{p}$ value $<0.05$ ) the Wilcoxon statistical test is performed.

Results: The results of the analysis of brain tumors are followed by manual measurement of tumor volume using the region growing technique. It requires sufficient expertise and experience so that the diagnosis of tumor volume is given precisely and accurately so that its handling can be carried out wisely Evaluation of MRI images requires high accuracy, but doctors can make mistakes because the diagnosis is still done manually, such as errors in diagnosing the location of the tumor and the size of the object. The very complex structure of the human brain also presents its own difficulties in identifying brain tumors. Subjective factors can also affect manual doctor evaluations such as fatigue and uncontrolled time in evaluating an MRI image so that a digital image processing program is needed that can be done with a computational machine to assist doctors in evaluating an MRI image automatically. The active contour method can solve the problem of topological changes in a brain tumor image.

Conclusion: The active contour method is able to classify images with high accuracy. So that it can increase the accuracy of the segmentation process for easy and fast medical diagnosis. The calculation of the volume of brain tumors can be done using the binaryization method which has been segmented through the final image produced by the active contour method. Tumor segmentation and automatic tumor volume calculation have great potential in clinical treatment by freeing doctors from the burden of manual labeling, digital image processing of brain tumors using the active contour method can be used as a complement to the MRI modality that radiologists can use in calculating brain tumor mass volume calculations.
\end{abstract}

Keyword : tumor calculation volume; active contour methode; region growing; digital image processing. 


\section{Pendahuluan}

Tumor otak merupakan sekumpulan massa dari sel-sel otak yang tumbuh secara abnormal (Astuti LW, 2019). Dalam istilah radiologisnya, tumor otak disebut dengan lesi desak ruang atau Space Occupying Lesion (SOL) yang secara umum mempunyai arti benjolan. Diagnosis tumor otak dapat dilakukan dengan menggunakan citra hasil dari pemeriksaan Magnetic Resonance Imaging (MRI) Brain (Astuti SD, 2017). MRI Brain mampu memvisualisasikan struktur internal otak manusia secara rinci. Protokol pemeriksaan MRI Brain meliputi pengambilan citra dengan pulsa squence rutin dan advanced teknik diantaranya Turbo Spin Echo (TSE), Diffusion Weighted Imaging (DWI), Fluid Attenuated Inversion Recovery (FLAIR), Magnetic Resonance Angiography (MRA) dan juga Magnetic Resonance Venography (MRV) (Amaral $\mathrm{G}$, et al, 2013).

Radiologis atau dokter spesialis radiologi dalam mengidentifikasi tumor otak akan menganalisa citra hasil MRI Brain dengan teknik post processing menggunakan menu dalam editor 3D yang disebut dengan teknik region growing (Manual B.). Hasil analisa tumor otak dilanjutkan dengan pengukuran volume tumor secara manual menggunakan teknik region growing, dibutuhkan keahlian dan pengalaman yang cukup agar diagnosa volume tumor yang diberikan tepat dan akurat sehingga penanganannya pun dapat dilakukan dengan bijak (Varijki E. et al, 2017). Evaluasi citra hasil MRI memerlukan ketelitian dan ketepatan yang tinggi, akan tetapi dokter dapat melakukan kesalahan karena diagnosa yang dilakukan masih secara manual seperti kesalahan dalam mendiagnosa letak tumor dan juga ukuran obyek (Murinto. At al, 2011). Struktur otak manusia yang sangat kompleks juga memberikan kesulitan tersendiri dalam identifikasi tumor otak (Khan Y. at al, 2017). Faktor subjektif juga dapat mempengaruhi evaluasi dokter secara manual seperti kelelahan dan waktu yang tidak terkontrol dalam mengevaluasi suatu citra MRI sehingga dibutuhkan suatu program pengolahan citra digital yang dapat dilakukan dengan mesin komputasi untuk membantu dokter dalam mengevaluasi suatu citra MRI secara otomatis (Roy S, 2012).

Pengolahan citra digital memungkinkan diperolehnya indikator kunci yang berguna untuk perkembangan penyakit termasuk dalam evaluasi suatu kasus tumor otak. Segmentasi tumor dan perhitungan volume tumor pada MRI adalah tindakan yang penting dalam mengevaluasi suatu kasus tumor otak (Roy S, 2012). Segmentasi adalah proses mempartisi gambar ke dalam kelompok piksel yang identik sehubungan dengan beberapa kriteria. Segmentasi dalam diagnosa tumor memiliki bagian penting dalam pengobatan tumor otak karena segmentasi merupakan filterasi terbaik untuk dapat memisahkan area tumor dan non tumor dalam suatu citra MRI (Khan Y. at al, 2017). Salah satu metode segmentasi tumor otomatis yang dapat diterapkan pada berbagai kondisi citra adalah metode Active contour. Active contour merupakan teknik segmentasi citra yang sensitif, adaptif, dan mudah menemukan batas-batas objek yang penuh noise atau tidak jelas (Diah Priyawati, 2015). Metode active contour dapat mengatasi masalah perubahan topologi pada suatu citra tumor otak. Metode active contour mampu mengelompokkan citra dengan akurasi tinggi. Sehingga dapat meningkatkan akurasi proses segmentasi untuk diagnosis medis menjadi mudah dan cepat. Perhitungan volume tumor otak dapat dilakukan dengan metode binerisasi yang telah tersegmentasi melalui citra akhir yang dihasilkan dengan metode active contour. Segmentasi tumor dan perhitungan volume tumor secara otomatis memiliki potensi besar dalam pengobatan klinis dengan membebaskan dokter dari beban pelabelan secara manual (Diah Priyawati, 2015). Pada penelitian ini diusulkan suatu program pengolahan citra digital untuk menghitung volume tumor otak secara otomatis dengan menggunakan proses segmentasi metode Active Contour. mengingat belum adanya software otomatis sebagai pelengkap dalam modalitas MRI yang dapat radiologis gunakan dalam menghitung kalkulasi volume massa tumor otak.

\section{Metode}

Jenis penelitian adalah quasi eksperimen menggunakan rancangan penelitian Posttest Only Without Control Group Design. Penelitian ini bertujuan untuk mengetahui adanya perbedaan pada hasil pengukuran volume tumor menggunakan teknik region growing pada pesawat MRI Siemens 1,5 Tesla dan dengan proses segmentasi metode active conntour (post-test). Rencana penelitian akan dilakukan di RS Hermina Bekasi dengan menggunakan 32 sampel citra MRI tumor otak, 
besar sampel didapatkan dengan rumus besar sampel terhadap rerata dua populasi berpasangan sesuai dengan Sastroasmoro (2011). Analisis data bivariat, apabila data berdistribusi normal ( $p$ value >0,05), maka dilakukan uji statistic Paired T-test dan apabila data berdistribusi tidak normal ( $p$ value <0.05) dilakukan uji statistik Wilcoxon (Ayu).

\section{Hasil dan Pembahasan}

Pemeriksaan citra hasil MRI memerlukan ketelitian dan ketepatan yang tinggi

Murinto (2011) menyebutkan bahwa salah satu kesulitan dalam diagnosa tumor otak adalah membedakan organ tumor dan non tumor, atau melakukan manipulasi pada satu objek saja tanpa meyentuh objek lain, dan sulitnya memisahkan objek satu dengan objek yang lain (Segmentasi).

Dokter dapat melakukan kesalahan karena proses segmentasi yang dilakukan masih secara manual seperti kesalahan dalam mendiagnosa letak atau besar kecilnya obyek tumor. Selanjutnya Khan Y (2017) menyebutkan Struktur otak manusia yang sangat kompleks juga merupakan kesulitan tersendiri dalam identifikasi tumor otak, selain itu faktor subjektif juga dapat mempengaruhi evaluasi dokter secara manual seperti kelelahan dan waktu yang tidak terkontrol dalam mengevaluasi suatu citra MRI. menjawab kesulitan dalam identifikasi tumor otak Roy (2012) menyarankan suatu program pengolahan citra digital dalam membantu diagnose tumor otak. Pengolahan citra digital memungkinkan diperolehnya indikator kunci yang berguna untuk perkembangan penyakit termasuk dalam evaluasi suatu kasus tumor otak. Diah (2015) melaporkan segmentasi tumor dan perhitungan volume tumor secara otomatis memiliki potensi besar dalam pengobatan klinis dengan membebaskan dokter dari beban pelabelan secara manual.

Penelitian Fitriyah (2019) melaporkan bahwa proses penggambaran tumor otak GTV, CTV, PTV, dan OAR pada perencanaan terapi selama ini dilakukan secara manual dan membutuhkan waktu yang tidak sedikit sehingga diperlukan program untuk mempercepat proses penggambaran tersebut. Fitriyah mengusulkan metode active contour untuk melakukan delineasi target volume. Delineasi target volume yang akurat merupakan elemen penting dalam proses TPS. Untuk meningkatkan visualisasi dan membantu dalam penggambaran volume selama perencanaan radioterapi. Hasil penelitian menunjukkan keakuratan metode active contour untuk menentukan CTV tumor otak. selanjutnya Perhitungan volume tumor dimulai dengan menghitung luas target di setiap irisan menggunakan Simpson integration formula. Simpson integration formula dapat digunakan untuk menghitung luas target yang hasilnya mendekati hasil perhitungan luas target manual. Range error rate yang didapat adalah luas 0,0006 sampai 0,0059, dan juga untuk target volume dengan range rate error untuk aksial 0,0001 sampai $0,0013^{12}$.

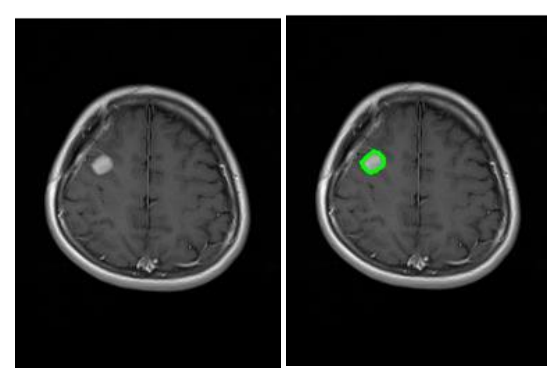

Gambar 1 (a) original image (b) hasil GTV contour (Fitriyah W, 2019)

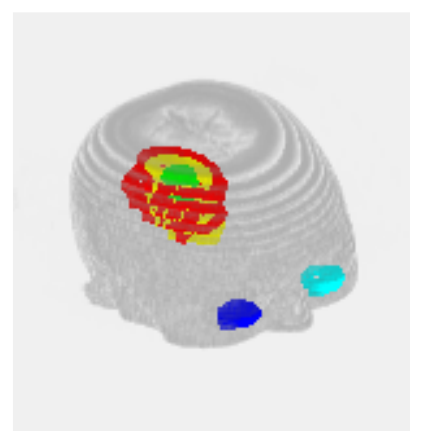

Gambar 2 Display 3D target volume (Fitriyah W, 2019)

G. Anand (2019) dalam penelitiannya menyebutkan bahwa active contour membentuk kontur gambar tanpa preprocessing dan melindungi detail gambar. Lapisan dalam jaringan konvolusional 3D mengekstrak fitur spasial dan temporal gambar. Setelah segmentasi, volume tumor dapat diperkirakan menggunakan metode Extended Gauss untuk memberikan pengobatan dan estimasi dosis yang lebih baik. Hasil pengujian dievaluasi menggunakan dataset BRATS yang membuktikan keefektifan segmentasi active contour dan memperkirakan volume tumor MRI, dilaporkan bahwa penelitian segmentasi citra tumor otak dan perhitungan volume tumor menggunkan metode active contour mencapai hasil yang lebih baik (Kumar GA. At al, 2019). 


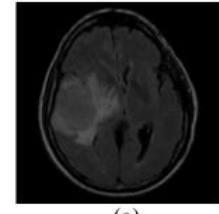

(a)

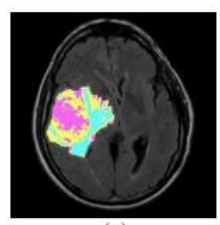

(c)
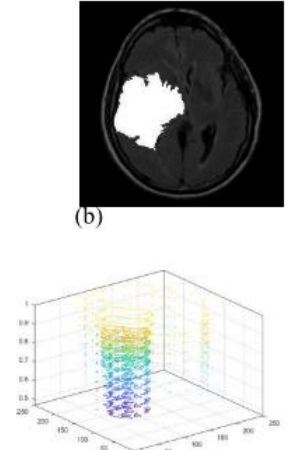

(d)
Gambar 3 (a) original brain image

(b) brain tumor (c) hasil segmentasi (d) 3d plot tumor.

\section{Simpulan}

Segmentasi tumor dan perhitungan volume tumor secara otomatis memiliki potensi besar dalam pengobatan klinis dengan membebaskan dokter dari kesulitan identifikasi tumor secara manual. segmentasi dan perhitungan volume tumor secara otomatis dapat dilakukan menggunakan program pengolahan citra digital yang dapat digunakan sebagai pelengkap dalam modalitas MRI yang dapat radiologis gunakan dalam menghitung kalkulasi volume massa tumor otak.

\section{Daftar Pustaka}

Astuti LW. Ekstrasi Fitur Citra MRI Otak Menggunakan Data Wavelet Transform (DWT) untuk Klasifikasi Penyakit Tumor Otak. J Ilm Inform Glob. 2019;10(2):80-6.

Astuti SD, Aisyiah N, Muzammil a. Analisis kualitas citra tumor otak dengan variasi flip angle (FA) menggunakan sequence $\mathrm{T} 2$ turbo spin echo axial pada magnetic resonance imaging (MRI). Pertem Ilm Tah Fis Medis dan Biofisika 2017. 2017;1(1):86-90.

Amaral G, Bushee J, Cordani UG, KAWASHITA K,
Reynolds JH, ALMEIDA FFMDE, et al. No 主観的健康感を中心とした在宅高齢者におけ る

健康関連指標に関する共分散構造分析Title. Vol. 369, Journal of Petrology. 2013. 1689-1699 p.

AYU. Statistik untuk Kedokteran dan Kesehatan - Google Books [Internet]. Available from: https://books.google.co.id/books?hl=en\&lr=\&id= Abh5OaO3qlMC\&oi=fnd\&pg=PA1\&dq=kedokte ran\&ots=SWQDIh73wY\&sig=QezPgRQqZMT_a iayBz_rMqhx2Vo\&redir_esc $=\mathrm{y} \# \mathrm{v}=$ onepage $\& \mathrm{q}=\mathrm{k}$ edokteran $\& \mathrm{f}=$ false

Diah Priyawati, Indah Soesanti IH. Kajian Pustaka Metode Segmentasi Citra Pada Mri Tumor Otak. 2015;207-15.

Fitriyah W, Evi Setiawati, Adi K. Delineation of Target Volume for Brain Tumors in Radiotherapy Using Active Contour Segmentation and Simpson Integration. Int $\mathbf{J}$ Eng Technol Manag Res [Internet]. 2020;6(6):137-45. Available from: http://dx.doi.org/10.29121/ijetmr.v6.i6.2019.403

Khan Y, Prof A, Bhatia A. Active Contour Based Segmentation for Brain Tumor Segmentation in MRI. 2017;6(11):1165-71.

Kumar GA, Sridevi P V. Active contour model for brain $\mathrm{mr}$ tumor segmentation and volume estimation. Int J Eng Adv Technol. 2019;9(1):7226-31.

Manual B. syngo MR D13.

Murinto, Rahnawati RF. Segmentasi Citra Medik MRI ( Magnetic Resonance Imaging ) Menggunakan SEGMENTASI CITRA MEDIK MRI MAGNETIC RESONANCE IMAGING ) MENGGUNAKAN METODE. Stud Tek Inform. 2016;(July 2011).

Roy S, Bandyopadhyay SK. Detection and Quantification of Brain Tumor from MRI of Brain and it's Symmetric Analysis. Int J Inf Commun Technol Res [Internet]. 2012;2(6). Available from: http://www.esjournals.org

Sastroasmoro S. Perkiraan Besar Sampel dalam Penelitian Klinis. Dasar-dasar Metodol Penelit. 2011;359.

Varijki E, Triwijoyo BK. Segmentasi Citra Mri Menggunakan Deteksi Tepi Untuk Identifikasi Kanker Payudara. J Matrik. 2017;15(2):17. 